\title{
India: Mobility Trends
}

\section{WESLEY TETER and DON MARTIN}

Wesley Teter is a senior consultant on higher education. E-mail: Wesley.Teter@gmail.com. Don Martin is an enrollment management expert. Email:dmartin@gradschoolroadmap.com.

After years of declines, the latest trends in international student enrollment in the United States from India show signs of a dramatic turnaround. In April 2013, the Council of Graduate Schools announced that applications from India to US graduate programs increased 20 percent, compared to a mere 1 percent increase worldwide. Similarly, the Education Testing Service reported that the Graduate Record Examination test volume in India for 2012 grew by approximately 30 percent compared to the prior year, which indicates a strong interest in graduate studies abroad. Most importantly, the American Embassy in New Delhi also confirmed that early data on student visa approvals showed an increase of a staggering 50 percent from October 2012, through early 2013 compared to the same period last year. These indicators of renewed growth are even more significant in the context of substantial declines in new enrollments from India over the past four years. 


\section{MOBILITY TRENDS}

From 2009 to 2012, US enrollments from India decreased 17 percent at a graduate level and 16 percent at an undergraduate level—a downward spiral that was significantly underreported for a variety of reasons. For example, the total number of students from India studying in the United States held steady during this period (down just 3\%). At the same time, Indian student participation in postgraduation internships—known as optional practical training—surged 80 percent over the same period, compared to a 28 percent increase worldwide. Participation in that training, particularly among science, technology, engineering, and mathematics students who can work up to 29 months, offset the declines and gave a skewed picture of the reality of student mobility trends from India.

In terms of fields of study among mobile students, the popular search engine (GradSchools.com) confirmed that engineering management and construction management are among the top three, most-popular searches by visitors from India. The related issues outlined below are expected to drive future mobility and should therefore act as a foundation for developing a longterm view for student recruitment.

\section{CAReErs and Job Prospects}

An astounding 54 percent of India's 1.2 billion people are under the age of 25 . India's "demographic dividend," coupled with a rising middle class, is expected to propel demand for education and training and play a major role in the country's future economic development. However, India's economy for the fiscal year that ended in March 2013 grew by a relatively weak five percent-the 
slowest in a decade. Students and their families believe a US degree offers a competitive advantage for better jobs in an increasingly globalized job market.

Career prospects and return on investment are crucial factors to highlight when recruiting in India. Optional practical training, internships, and career services often help to justify a family's once-in-a-lifetime investment. For example, according to the National Science Foundation, doctoral students are particularly attracted by career prospects in the United States. Graduates from China, countries that were part of the former Soviet Union, and India reported distinctly low rates of returning to their home countries $(3.7 \%, 4.1 \%$, and $5.2 \%$, respectively) compared with those from other foreign countries. In fact, Indian nationals were number one in the world for obtaining specialized US work visas known as the $\mathrm{H}-1 \mathrm{~B}$, securing an impressive 59 percent of the global total. Unfortunately, few institutions in the United States make a compelling argument about career prospects when returning to India with a US degree. Surprisingly, few success stories involve young graduates returning to launch their careers.

Student recruitment efforts in India should begin with helping students understand their academic and career goals and how a particular institution in the United States fulfills those needs. Institutions such as Tri-Valley, which was investigated for visa fraud by Immigration and Customs Enforcement in 2011, should not be allowed to dominate the discourse about education to employment prospects. US institutions can help their students overcome these challenges, by ensuring applicants can explain to a consular officer why and how they chose a particular school. Applicants who are unable to do so or are singularly focused on their career interests in the United States are unlikely to be granted a student 
visa. These prospective students would have to reapply for a visa or consider their options elsewhere.

\section{AcCess to Quality Higher Education}

Given limited access to quality education in India, a growing number of students turn to the United States, United Kingdom, Australia, and low-cost options closer to home. Part of the challenge is that local quality institutions, such as the Indian Institutes of Technology and Indian Institutes of Management, are highly competitive and unable to meet local demand. Due to a struggling qualityassurance system, second-tier institutions are of widely varying standards. The world-class status of universities and colleges in the United States helps to justify the high cost of tuition.

When considering study-abroad destinations, rankings and perceptions of academic quality are the most important elements that prospective students in India and their families are evaluating when considering study-abroad destinations. In terms of recruitment, it is critical that US institutions highlight academic rigor and not "frills" such as new sports facilities, dining halls, and elaborate dorms, which add to the cost of education and have less to do with the quality of the academic experience or future employment prospects.

\section{NeW FinANCing Strategies}

High inflation and the increasing cost of US tuition are major barriers to study abroad, particularly at the undergraduate level. Renuka Raja Rao, Country Coordinator for EducationUSA in India adds that "As the number one destination for study abroad, the question most students in India ask is not why 
study in the US, but how." The falling value of the Indian rupee, which dropped 22 percent from January 2009 to July 2013, is linked to the decline in student mobility to the United States. These dramatic shifts in currency value negatively impact a middle-class family's ability to invest in overseas education, even with partial scholarships. US institutions should not mistake recruitment opportunities in India as a means to overcome budget shortfalls. New financing strategies, such as creative academic partnerships and blended distance programs, are needed to overcome increasing costs for study abroad.

In the short term, participation in student recruitment fairs in India and an active social media presence can be highly effective outreach channels. Commercial service providers and recruitment agencies report substantial increases in the number of their students applying to US universities, yet little data are available related to visa approvals and other quality-control measures. US consular officers warn students that consultants sometimes "sell to students fake financial packages," which can lead to applicants being found permanently ineligible for visas, because they provided false information during an interview.

According to a survey by World Education Services, 46 percent of students from India selected "tuition and living costs" and 38 percent selected "financial aid opportunities" among their top three information needs. In contrast, the question that more and more US admissions officers ask is how to recruit self-funded undergraduate students without traveling to India, a question that illustrates financial pressures in the United States, but does little to reassure Indian families that US institutions have a genuine academic interest in recruiting talented students. Institutions with a compelling recruitment strategy, including scholarships or assistantships for science, technology, engineering, and 
mathematics fields, will be well-positioned to effectively recruit the next generation of leaders. 